\title{
Chukar Watering Patterns and Water Site Selection
}

\author{
Randy T. Larsen, ${ }^{1}$ Jerran T. Flinders, ${ }^{2}$ Dean L. Mitchell, ${ }^{3}$ Ernest R. Perkins, ${ }^{4}$ and David G. Whiting ${ }^{5}$ \\ Authors are ${ }^{1}$ Research Associate; ${ }^{2}$ Professor, Department of Plant and Wildife Sciences, Brigham Young University, 275 WIDB, Provo, \\ UT 84602; ${ }^{3}$ Upland Game Coordinator, Utah Division of Wildife Resources, PO Box 146301, Salt Lake City, UT 84114; ${ }^{4}$ Member, Utah Upland Game \\ Advisory Council, 3087 Maxine Drive, Layton, UT 84040; and ${ }^{5}$ Professor, Department of Statistics, Brigham Young University,
} 220 TMCB, BYU, Provo, UT 84602.

\begin{abstract}
We evaluated chukar (Alectoris chukar) watering patterns as well as habitat variables influencing water site selection in western Utah. Motion-sensing cameras and chukar dropping counts were primary techniques to evaluate watering patterns. We took vegetative and other habitat measurements at each water source $(n=43)$ to discriminate use from nonuse sites using logistic regression. Chukars watered during daylight hours with a modal hour from 1200 hours to 1300 hours daylight savings time. Annual patterns suggest limited use of water sources from November to May with first observed visits occurring in June and last observed visits in October. Shrub canopy cover was the only variable to discriminate between site types $(P<0.01)$. Cross validation showed a predictive success rate of $84 \%$. Significant differences were found between use and nonuse sites in terms of security cover $(P<0.01)$, but not total cover $(P>0.05)$. Chukars seem to have a loose shrub canopy threshold near $11 \%$ that is likely due to predation risk. Water sources meeting this threshold received use, whereas those not meeting this threshold did not. Increasing shrub canopy cover above $11 \%$ did not translate into increased water source use. Managers might want to consider annual patterns when setting hunt season timing and structure as well as judging sites for new water developments based on shrub canopy cover. More generally, these results suggest a behavioral constraint on the use of water sources as a function of predation risk-we should expect other species to demonstrate similar behavioral constraints. These constraints must be considered in any effort to determine benefits or impacts of water developments.
\end{abstract}

\section{Resumen}

Evaluamos los patrones de toma de agua del "Chukar" (Alectoris chukar), así como variables del hábitat que influencian en la selección del aguaje en el oeste de Utah. Las técnicas principales para evaluar los patrones de toma de agua fueron cámaras con sensor de movimiento y conteos deposiciones de "Chukar." Tomamos mediciones de la vegetación y del hábitat en cada aguaje $(n=43)$ para discriminar los sitios de uso y no uso mediante regresión logística. Los "Chukars" se abastecen de agua durante las horas con luz y la moda fue de las 1200 a las 1300 horas. Los patrones anuales sugieren el uso limitado de los aguajes de noviembre a mayo, las primeras vistas observadas ocurrieron en junio y las últimas en octubre. La cobertura de copa de los arbustos fue la única variable para discriminar entre tipos de sitio $(P<0.01)$. La validación cruzada mostró una tasa éxito de predicción de $84 \%$. Se encontraron diferencias significativas entre los sitios de uso y no uso en términos de cobertura de seguridad $(P<0.01)$, pero no para la cobertura total $(P>0.05)$. Los "Chukars" parecen tener un umbral de la copa de arbustos cercana al $11 \%$, debido probablemente al riesgo de predación. Los aguajes que cumplen con este umbral recibieron uso, mientras que aquellos que no reunieron esta condición no se utilizaron. Aumentar la cobertura de copa de arbustos a más del $11 \%$ no se tradujo en un aumento en el uso de los aguajes. Los manejadores pueden querer considerar los patrones anuales al fijar la época y estructura de la estación de caza, así como para evaluar el desarrollo de nuevos sitios de aguaje en base a la cobertura de copa de los arbustos. Más generalmente, estos resultados sugieren una limitante de comportamiento en el uso de las fuentes de agua en función del riesgo de predación, esperamos que otras especies demuestren limitantes de comportamiento similares. Estas limitantes deben ser consideradas en cualquier esfuerzo para determinar los beneficios o impactos del desarrollo de aguajes.

Key Words: Alectoris chukar, guzzlers, logistic regression, security cover, water developments

\section{INTRODUCTION}

Chukars (Alectoris chukar) have been widely introduced throughout the world. The most successful widespread

Brigham Young University, Carson Valley Chukar Club, Nevada Chukar Foundation, Pershing County Chukars Unlimited, Pheasants Forever (Salt Lake Chapter), Salt Lake County Fish and Game Association, Sportsmen for Fish and Wildlife, Utah Division of Wildlife Resources, and Water for Wildlife Foundation provided financial support of this research.

Correspondence: Randy T. Larsen, Dept Plant and Wildlife Sciences, 275 WIDB, Brigham Young University, Provo, UT 84602. Email: randy_larsen@byu.edu

Manuscript received 23 March 2006; manuscript accepted 16 August 2007. introductions occurred in North America (Long 1981) where chukars now occupy roughly $252800 \mathrm{~km}^{2}$ of habitat in 11 western states and one Canadian province (Christensen 1996). Habitat management for chukars has generally been limited to water development with particular emphasis placed on the installation of rainwater catchments (guzzlers) to expand populations into new areas (Christensen 1970; Benolkin and Benolkin 1994). Nevada, for example, has installed over 1500 guzzlers, many of which are designed to benefit chukars (Nevada Division of Wildlife 1999).

Despite sizeable monetary investments in water developments, agencies and researchers have yet to clearly demonstrate 
their effectiveness (Rosenstock et al. 1999). Perhaps one reason is a failure in many efforts to account for probability of use by target species. Benolkin (1988) dealt with this issue when after years of involvement in Nevada's water development program, he hypothesized that the reason many guzzlers intended to benefit chukars were not used by them was related to poor placement. Based on experience, he suggested that chukars would not use guzzlers unless they were 1) located in canyon bottoms where a natural spring might occur and 2) were placed near (within $10 \mathrm{~m}$ ) a steep hill or cliff. He further suggested that severe wildfire where sagebrush had been eliminated would preclude chukar establishment until the overstory was restored.

This hypothesis remains untested, and to our knowledge no quantitative data are available regarding watering patterns, watering site use, or important habitat variables that might influence water site selection by chukars. Accordingly, our specific objectives of investigation were 1) to describe chukar watering patterns, 2) to identify proximate habitat variables important in predicting chukar use of water developments, and 3) to test Benolkin's (1988) hypotheses concerning the importance of guzzler placement. In addition, we tested the simple hypothesis-formulated by observation in the fieldthat used watering sites have significantly higher mean security cover values (shrubs and trees) than unused sites, but not differences in mean total cover values (all vegetation combined to include forbs and grasses). Results of this research should contribute to more effective water projects because at least 10 western states have ongoing water development programs (Rosenstock et al. 1999).

\section{STUDY AREA}

We evaluated 43 water sources (six springs and 37 guzzlers) for use by chukars in three different areas of western Utah located in Box Elder, Juab, and Tooele counties. These water sources included a majority of guzzlers from both the north end of the Pilot Mountains and the south end of the Grouse Creek/Bovine Mountains, Box Elder County (centered at lat $41^{\circ} 24^{\prime} 14^{\prime \prime} \mathrm{N}$ long $\left.113^{\circ} 54^{\prime} 34^{\prime \prime} \mathrm{W}\right)$; all known guzzlers and springs on the Keg Mountains, Juab County (centered at lat $39^{\circ} 47^{\prime} 8^{\prime \prime} \mathrm{N}$ long $112^{\circ} 52^{\prime} 22^{\prime \prime} \mathrm{W}$ ); and all known water sources north of Hastings Pass Road on the Cedar Mountains, Tooele County (centered at lat $40^{\circ} 44^{\prime} 22^{\prime \prime} \mathrm{N}$ long $\left.112^{\circ} 54^{\prime} 20^{\prime \prime} \mathrm{W}\right)$. We selected water sources for evaluation in Box Elder County based on access and proximity to each other with an attempt to evaluate all known water sources on several small foothill ranges of both the Pilot and Grouse Creek/Bovine Mountains.

All three study areas are encompassed within the Great Basin physiographic region, characterized by roughly parallel mountain ranges separated by desert basins (Fenneman 1931), hot summers (Dice 1943), and a deficiency of precipitation at all seasons (Thornthwaite 1931). Annual precipitation averages from 102 to $508 \mathrm{~mm}$ and daily summer temperature extremes differing between $4.4^{\circ}$ and $10^{\circ} \mathrm{C}$ are typical (Christensen 1996). Water sources ranged in elevation from 1473 to $1922 \mathrm{~m}$ and were all located within the range of chukar distribution. All guzzlers evaluated were designed and intended to benefit chukars as a primary species, whereas all springs included in analysis were located in steep, rocky, mountainous terrain characteristic of chukar habitat (Christensen 1996).

Abundant native trees in each study area included juniper (Juniperus sp.) and pinyon pine (Pinus edulis Engelm.). Native shrubs found were sagebrush (Artemisia sp.), Mormon tea (Ephedra sp.), Mexican cliff rose (Cowania mexicana D. Don), curl leaf mountain mahogany (Cercocarpus ledifolius Nutt. in T. and G.), saltbush (Atriplex sp.), and others. A partial list of common grasses and forbs includes the following: cheatgrass (Bromus tectorum L.), bluebunch wheatgrass (Elymus spicatum Pursh), indian rice grass (Stipa hymenoides Roem. and Schult.), needle and thread grass (Stipa comata Trin. and Rupr.), sandberg bluegrass (Poa secunda Presl), halogeton (Halogeton glomeratus Bieb.), Russian thistle (Salsola iberica Sennen and $\mathrm{Pau}$ ), and redstem filaree (Erodium cicutarium [L.] L'Her.).

\section{METHODS}

Beginning in May of 2003 and 2004, we visited water sources and cleared a $12-\mathrm{m}^{2}$ area (centered at the guzzler or spring) of all chukar droppings. We visited each water source approximately every 2 weeks to count and clear droppings throughout both summers, terminating by October. Dropping counts were conducted on 33 of the $43(77 \%)$ sites in 2003 and all sites in 2004. Watering sites where dropping counts were not made in 2003 were monitored with cameras and/or visits (at least once at the end of the summer) where we looked for chukar sign (feces, feathers, tracks, etc.) to establish use or nonuse for 2003. To verify use and document watering patterns, we placed digital motion-sensing cameras (The Digital 3.2; Camtrakker Inc ${ }^{\circledR}$, Watkinsville, GA) at guzzlers and springs beginning in May and ending in December (one camera per site over a given time interval) such that approaching animals triggered the cameras. We set cameras to operate continuously and placed them 1-2 $\mathrm{m}$ from water available for drinking to minimize problems associated with differential detection (Cutler and Swann 1999). We moved cameras sequentially to different guzzlers and springs every 2 weeks. Water sources generally received 4 weeks of photographic sampling each year.

We made the following measurements at each site during late summer or early fall: distance to nearest rock cover (defined as a collection of two or more boulders of sufficient size to offer cover for a chukar), distance to the nearest shrub, distance to the nearest road (regardless of improvement), average shrub density, percent shrub canopy cover, average shrub height, horizontal obscurity cover (both total and shrub/tree only), and vertical obscurity cover (both total and shrub/tree only).

We measured vertical and horizontal obscurity with cover boards (Bunnell et al. 2004) placed at predetermined locations along $30-\mathrm{m}$ belt transects originating from the center of watering sites in each of the cardinal directions. Horizontal cover boards measuring $1 \times 1 \mathrm{~m}$ were divided into 36 equal squares and read from distances of $2.5,5$, and $10 \mathrm{~m}$ along each transect. Vertical obscurity cover boards (measuring $18 \times 18 \mathrm{~cm}$ and divided into 36 equal squares) were read at $2.5,5,10,15,20$, and $30 \mathrm{~m}$. We read cover boards either from directly overhead (vertical obscurity) or from a height of 12$25 \mathrm{~cm}$ (horizontal obscurity). 
We estimated average shrub density, percent shrub canopy cover, and average shrub height along $30-\mathrm{m}$ belt transects (Mueller-Dombois and Ellenberg 1974) extending in each of the four cardinal directions. All shrubs and trees rooted within $1 \mathrm{~m}$ of the transect line on either side were measured for height and area within the canopy (calculated as the area of an ellipse). We then calculated percent shrub canopy cover as the percentage of sampled area $\left(240 \mathrm{~m}^{2}\right)$ occupied by shrub canopy. To test Benolkin's (1988) hypothesis about the need to place guzzlers in canyon bottoms, we created an additional factor variable to represent the general description of the watering site as 0 (in a canyon or ravine bottom) and 1 (not in a canyon or ravine bottom).

We obtained two different measures of slope from a 30-m resolution digital elevation model. These included the immediate slope (defined as the slope of the pixel on which the water source is located) and the average slope for the area (determined by averaging slope values from pixels within the area of a circle centered at the water source with a radius of $280 \mathrm{~m}$ ). Prior research (Lindbloom 1998; Walter 2002) has estimated daily movement at or near this value. We calculated both immediate slope and average slope using options available with ArcMap ${ }^{\circledR}$ (Version 9.1; ESRI, Redlands, CA).

We estimated mean and modal watering times by using the time stamps from all photographs depicting chukars. To more accurately compare 2003 with 2004 (given the larger sample in 2004), we converted dropping counts at each interval to relative percents. Dates of first and last visits for each year are reported based on time and date stamps associated with photographs. Coarse comparisons of dropping counts with average temperatures were made with weather data from Wendover, UT obtained from www.wunderground.com.

In habitat analyses, we used a two-stage approach by first using logistic regression (Hosmer and Lemeshow 2000) in a backwards stepwise elimination procedure based on significance (alpha level $P=0.05$ ) to identify which of the measured variables (both slope measures, distance to rock cover, distance to nearest shrub or tree, distance to nearest road, percent shrub canopy cover, average shrub height, and the factor variable describing location) were important in discriminating use from nonuse sites. We defined use sites as watering sources where droppings were counted and/or chukars photographed between May and December in either year.

Independent variables were evaluated for correlation to avoid problems with multicollinearity. We excluded average shrub density due to high correlation and redundancy with percent canopy cover $(r=0.58 ; P<0.01)$. Both measures were calculated along the same belt transect and originate from the same shrub-area interaction. We retained percent shrub canopy cover due to a long tradition of use and interpretation in wildlife sciences across a broad range of species and habitats (e.g., Turchi et al. 1995; Main 1996).

Prior to analysis, we divided the sample $(n=43)$ into five randomly assigned groups for cross validation. Variable elimination was evaluated based on significance levels with samples from four of the five groups pooled together. We conducted all five step-wise iterations of this procedure and report these results along with results from the full model accordingly. Each of the resulting five models was then tested on the withheld group of observations. Percent concordance is reported as a measure of the model's ability to discriminate between site types. In addition, we report significance levels from Hosmer and Lemeshow's (2000) goodness-of-fit test, which is an indication of gross lack of fit and model inadequacy (Vittinghoff et al. 2005). We used a classification tree (De'ath and Fabricius 2000) to provide quantitative support for a value associated with discriminating variables.

In the second stage of analysis, we evaluated habitat variables against our relative abundance measure (summer dropping counts) using least-squares regression to try and further understand underlying mechanisms. This analysis was conducted with the mean value (or the 2004 count if no relative abundance measure made in 2003) for the natural logarithm of each year's dropping counts (excluding the nonuse sites) as the dependent variable. Given a reduced sample size after exclusion of sites with a zero count, we made univariate evaluations for each independent variable.

To test our hypothesis of differences in mean security cover values between use and nonuse sites, but not differences in mean total cover values, we compared obscurity measures with $t$-tests adjusted for multiplicity with a Bonferroni correction (Ramsey and Schaffer 2002). Due to violation of the normality assumption caused by bounds of zero and one for percentage measures, we used a logit transformation on all four obscurity measures. Assumptions of transformed data were then evaluated graphically and with a Levene's test for homogeneity of variance (Levene 1960). To conduct these analyses, we used Minitab $^{\circledR}$ (Release 13.31; Minitab Inc., State Collage, PA) and S-Plus ${ }^{\circledR}$ (6.2; Insightful, Seattle, WA).

\section{RESULTS}

Twenty-five of the $43(58 \%)$ watering sites (21 guzzlers and four springs) received use by chukars over the 2-year study period, whereas $18(42 \%)$ water sources (16 guzzlers and two springs) had no indication of use in either year. Use was consistent year to year with only one guzzler $(2 \%)$ showing use in one year, but not the other. Results from dropping counts and motion photography were consistent with no discrepancies classifying use or nonuse sites based on either method.

Chukars appeared at watering sites in June of each year with the first photograph on 6 June 2003 and 18 June 2004. The last photographs of chukars at watering sites were taken on 29 October 2003 and 15 October 2004. Counts of droppings followed similar patterns in both years-increasing slowly through June and the first half of July, jumping sharply during the last half of July, remaining high through August, and steadily decreasing in September to low levels by the end of that month (Fig. 1). This figure shows dropping counts generally following increases in average high temperatures, but with an initial lag in both years.

Chukars visited watering sites during daylight hours (results presented in daylight savings time) with the earliest time stamp at 0548 hours on 28 June 2004 and the latest daily visit occurring at 2146 hours on 22 June 2004. Median visit $(n=3558)$ was 1154 hours with the third quartile complete by 1417 hours. Chukars generally watered from mid-morning to early afternoon with a modal hour from 1200 to 


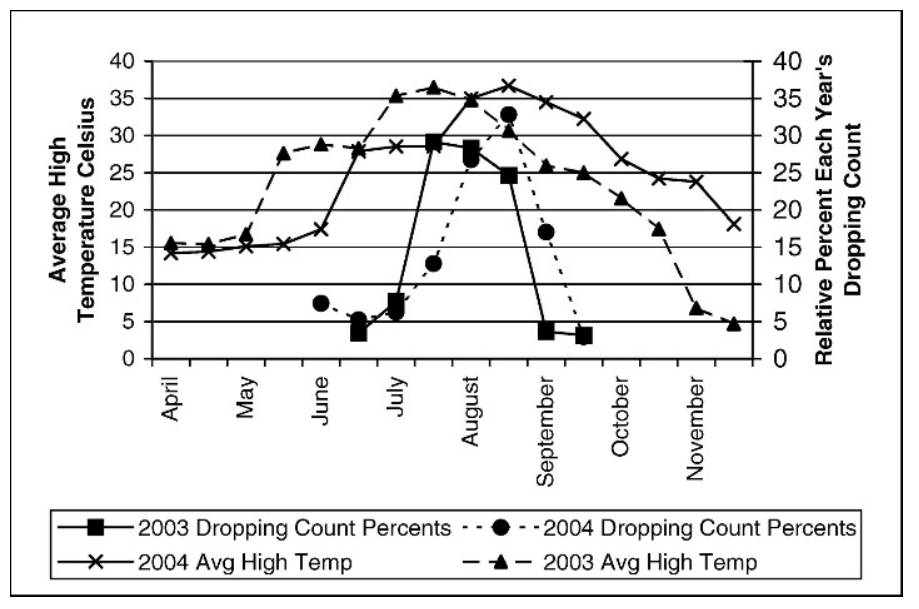

Figure 1. Relative percentages of each year's chukar droppings at water developments in relation to bimonthly average high temperatures from western Utah.

1300 hours, and the highest number of visits occurring between 1000 and 1400 hours (Fig. 2).

Both slope measures, distance to rock cover, distance to nearest shrub, distance to nearest road, average shrub height, and the factor variable describing location were eliminated $(P>0.05)$ in all stepwise iterations of cross validation, and the model developed with the full data set. Percent shrub canopy cover was the only variable to successfully discriminate between use and nonuse sites $(P<0.01$ and concordance $\geq 0.93$ ); correct prediction of withheld samples based on the model generated from all iterations was $84 \%$ (Table 1). Cross validation is used as the best indication of the model's predictive power when applied to observations not included in generation of respective models.

In the second stage of analysis, we evaluated variables univariately with least-squares regression on the natural logarithm of each year's dropping counts for use sites only. No significant relationships $(P>0.11)$ were detected in this second stage. Percent shrub canopy cover (the only significant variable in logistic regression) was not linearly related to counts of pellets at use sites $(P>0.47)$. The classification tree resulted in an initial branch split at $10.6 \%$ shrub canopy cover (misclassification rate $=7 \%$ ) consistent with Figure 3 .

We reject the null hypothesis of no difference in mean security cover values (shrubs and trees) between use and nonuse sites, but do not reject the null hypothesis of no difference in

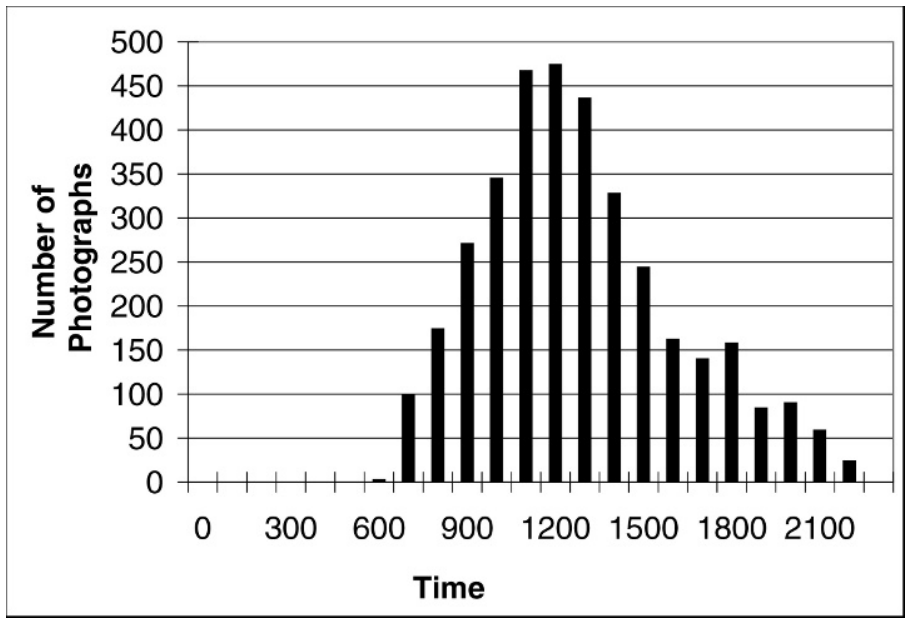

Figure 2. Histogram of chukar daily watering pattern based on time stamps $(n=3558)$ of photographs from guzzlers or springs in western Utah.

mean total cover values (shrubs, trees, grasses, and forbs). Untransformed mean values are reported for ease of interpretation with associated $P$ values calculated from transformed numbers. Total horizontal obscurity values for use $(0.82 \pm 0.03$, mean and SE) and nonuse $(0.77 \pm 0.05)$ sites did not differ $(P>0.44)$, nor did total mean vertical obscurity differ for use $(0.42 \pm 0.03)$ vs. nonuse $(0.40 \pm 0.03)$ sites $(P>0.52)$. Significant differences were found, however, with comparisons of obscurity measures between site types looking only at security cover. Mean values for the shrub and tree component of vertical obscurity cover $(0.28 \pm 0.02$ and $0.07 \pm 0.02)$ differed significantly $(P<0.001)$, as did mean values for the shrub and tree component of horizontal obscurity $(0.69 \pm 0.05$ and $0.20 \pm 0.06, P<0.001)$ between use and nonuse sites, respectively (Fig. 4).

\section{DISCUSSION}

We found use of guzzlers during the summer period consistent with other research showing that intensity of guzzler use by chukars is correlated inversely with moisture in vegetation (Nicolls 1961). Our results support this relationship between guzzler use and vegetation moisture content because dropping counts did not jump markedly until after mid-July, despite average high temperatures in late June near $30^{\circ} \mathrm{C}$ and average

Table 1. Summary table of significant variables discriminating chukar use from nonuse watering sites in logistic regression models and prediction accuracy on withheld samples.

\begin{tabular}{ccccccccc}
\hline Group & $n$ & Discriminating variable & $P$ & Concordance & Hosmer-Lemeshow & No. withheld & No. correctly predicted & \% \\
\hline 1 & 35 & Sh. can. cover & 0.003 & 0.963 & 0.422 & 8 & 7 & 0.88 \\
2 & 34 & Sh. can. cover & 0.006 & 0.957 & 0.287 & 0.298 & 9 & 8 \\
3 & 34 & Sh. can. Cover & 0.003 & 0.930 & 0.978 & 8 \\
4 & 35 & Sh. can. cover & 0.002 & 0.960 & 0.878 & 8 & 0.75 \\
5 & 34 & Sh. can. cover & 0.002 & 0.944 & 0.915 & 9 & 7 \\
Full model & 43 & Sh. can. cover & 0.001 & 0.951 & 0.426 & $43^{2}$ & $36^{2}$ & 0.78 \\
\hline
\end{tabular}

${ }^{1}$ Shrub canopy cover defined as the percent of shrub and tree canopy in sampled areas surrounding water sources.

${ }^{2}$ Sum.

${ }^{3}$ Average. 


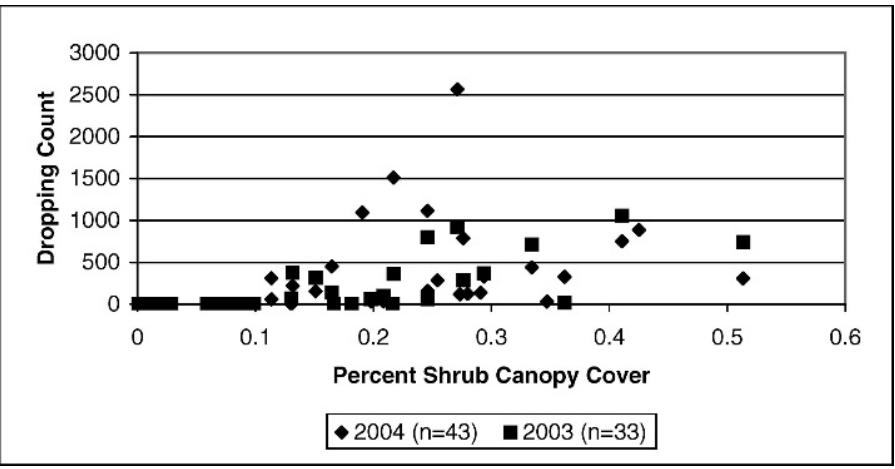

Figure 3. Summer chukar fecal dropping counts at watering sites in western Utah from both years in relation to percent shrub canopy cover.

high temperatures during the first half of July near or above $35^{\circ} \mathrm{C}$ (Fig. 1). This figure suggests that intensity of guzzler use was not immediately a function of air temperature and shows a lag perhaps attributable to relictual moisture in vegetative food items.

Annual patterns were also congruent with empirical evidence that chukars do not require free-standing water if succulent vegetation is available (Degen et al. 1982; Degen et al. 1984). By the end of September we found use had dramatically decreased and chukars were not photographed past October of either year, indicating that other sources of water (preformed, metabolic, or precipitation) during this period of cooler temperatures reduced reliance on water sources.

Circadian patterns depicted chukars generally watering during daylight hours with only a handful of photographs showing an activated flash. This pattern suggests that chukars are relatively inactive during nighttime darkness. Peak daily watering times between 1000 and 1400 hours (Fig. 2) suggest that other activities (such as foraging) generally occur before visits to water. In addition, decreased visitation during the late afternoon correlates with high ambient temperatures and is a time when chukars are known to loaf in the shade of shrubs and trees (Oelekaus III 1976).

Because location of guzzlers relative to canyon bottoms and both slope measures were not significant in predicting use or nonuse of guzzlers and were not significantly correlated to dropping counts, we rule out these effects for our study area. In fact, water sources used by chukars throughout this study were found in canyon bottoms, midslope, on benches, and along ridgelines. Furthermore, chukars used water sources located much farther than $10 \mathrm{~m}$ from steep hills or cliffs. Benolkin

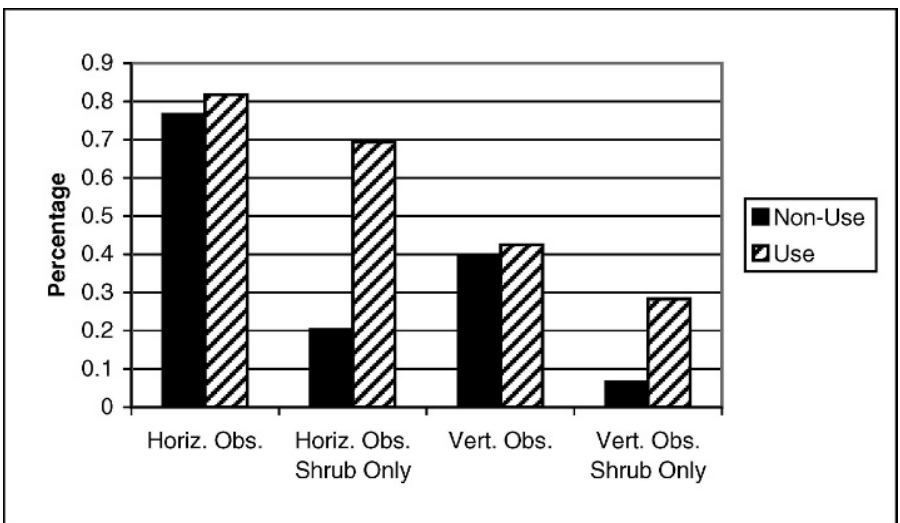

Figure 4. Comparisons of both horizontal (horiz.) and vertical (vert.) obscurity (obs.) values between chukar use and nonuse watering sites in western Utah showing shrub-only measures as significantly different $(P<0.001)$, but not total obscurity $(P>0.44)$.

(1988) surmised that chukars would look for water in areas where it might be expected naturally to occur in low-lying areas with natural constriction such as canyon bottoms. Natural sources of water such as springs and seeps, however, can occur in a tremendous variety of places, and our results confirm that chukars use guzzlers regardless of their placement in canyon bottoms within $10 \mathrm{~m}$ of steep escape terrain. The water sources we evaluated were operational for at least 8 years prior to study. It is unclear how long the guzzlers Benolkin evaluated had been operating prior to his work, nor how loosely he defined canyon bottom, which might help explain this discrepancy.

Benolkin's ideas (1988) about the negative impacts of fire on guzzler use by chukars are not discounted, and our data affirm the potential of fire to preclude use of watering sources by chukars. Presumably, this effect is due to elimination of security shrub cover, which we found to be the only consistent variable predicting use or nonuse. Both the measure of concordance and our cross validation indicated a good model for predicting guzzler use (Table 1).

Chukar selection of watering sources with sufficient security cover indicates predation risk from avian predators might influence chukar behavior. Review of the literature suggests that avian predators account for nearly half $(25 \%-100 \%)$ of all mortalities (Galbreath and Moreland 1953; Jonkel 1954; Bohl 1957; Messerli 1970; Shaw 1971; Lindbloom 1998; Walter 2000)-more than twice that of the next closest category (Table 2). Furthermore, chukars are a commonly reported prey

Table 2. Identified sources of mortality from all known studies of chukars in western North America.

\begin{tabular}{|c|c|c|c|c|c|c|c|c|}
\hline Source & Year & $N$ & Mammal & Avian & Hunting & Other & Unknown & $\%$ Avian \\
\hline Galbreath \& Moreland & 1953 & 21 & 3 & 13 & - & - & 5 & 62 \\
\hline Jonkel & 1954 & 53 & 9 & 17 & 6 & 6 & 15 & 32 \\
\hline Bohl & 1957 & 20 & 4 & 15 & - & - & 1 & 75 \\
\hline Messerli & 1970 & 4 & 2 & 1 & - & - & 1 & 25 \\
\hline Shaw & 1971 & 1 & - & 1 & - & - & - & 100 \\
\hline Lindbloom & 1998 & 17 & 7 & 10 & - & - & - & 59 \\
\hline Walter & 2000 & 27 & 7 & 10 & 6 & - & 4 & 37 \\
\hline Total & & 143 & 32 & 67 & 12 & 6 & 26 & $47^{1}$ \\
\hline
\end{tabular}

${ }^{1}$ Average value. 
item of raptors throughout the Great Basin and have been observed in nests of Golden Eagles (Aquila chrysaetos; Bloom and Hawks 1982) and Prairie Falcons (Falco mexicanus; Boyce 1985).

In addition to security cover, shrubs and trees provide thermal cover for chukars that show a preferred air temperature of $25.1^{\circ}-31.9^{\circ} \mathrm{C}$ in laboratory experiments (Laudenslager and Hammel 1977) and can often be found loafing beneath shrubs and trees near water during summer months (Oelklaus III 1976). Selection of watering sites with higher amounts of shrub cover also correlates well with research showing selection of shrub habitats by females with broods (Walter 2002; Lindbloom et al. 2003). In both our study years the majority of chukars in most photographs were young of the year. Other forms of cover (e.g., big boulders) around water sources could also provide adequate cover to both reduce predation risk and limit solar exposure during heat of the day.

The significance of shrub canopy cover in logistic regression, but not in least-squares regression with the natural logarithm of each year's dropping counts (use sites only) is suggestive of a loose threshold for security cover. Use of watering sources occurred above this threshold, but increasing levels of shrub canopy cover did not translate into increased dropping counts. The classification tree provides a value of $10.6 \%$ consistent with Figure 3, but did misclassify 3 of $43(7 \%)$ samples on the initial branch.

The distinction between total and security cover measured via cover boards has not, to our knowledge, been made prior to this study. Nonetheless, it was proven a valuable measure (Fig. 4) that helped clarify underlying mechanisms and we believe that drawing this distinction with other species and/or in other habitats could be of value. Cover boards can be easily read from the same location twice with one reading, accounting only for security cover (shrubs and trees), and the other evaluating total cover (forbs, grasses, shrubs, trees, etc.).

Our cross-validation approach provided a more conservative estimate ( $84 \%$ compared to $95 \%$, see Table 1$)$, but we argue a more robust way to estimate predictive power than concordance or other validations against the same data used to develop a given model. Our approach alleviates concernthrough evaluation-for cited problems of model selection using stepwise logistic regression, problems that can include selection of too few variables for a good prediction (Shtatland et al. 2001). Furthermore, cross validation allows model testing with observations not used in generation of respective models and avoids general criticism of wildlife sciences by Guthery et al. (2005). Cross validation and the distinction between security and total cover are two techniques that should be incorporated into future research efforts, including studies with other species and/or habitats-both are easily performed and provide more accuracy and resolution than traditional techniques.

Logistic regression in this study allows one to calculate (with proper transformation of the logit function) the probability that a given habitat (e.g., water source) is suitable, based on relatively few discriminating variables. As an example, using the model developed with the full data set $(n=43)$, the function describing differences between use and nonuse watering sites is as follows: logit $(\mathrm{Y})=-3.956+2.91$ (shrub canopy cover). With this function and appropriate exponentiation, calcula- tions of the probability that any water source in chukar habitat will be used or that a given area is acceptable for water development can be made based on an assessment of percent shrub canopy cover. Such an assessment is perhaps most appropriately made prior to new water development.

\section{MANAGEMENT IMPLICATIONS}

Managers may want to incorporate annual water source usage patterns into decisions affecting hunting season timing and structure. Water developments placed in areas that do not meet security cover requirements ( $\geq 11 \%$ shrub canopy cover) are unlikely to receive use by chukars and should not be built under the presupposition of benefiting chukar populations. In addition, fire that destroys security cover around watering sites will preclude establishment and use by chukars. Future research and management efforts should look at the effectiveness of rehabilitating the shrub habitat component around watering sources. Additional information concerning specific life-history characteristics of chukars such as brood mobility and brood habitat is desired due to the importance of this information in water source placement and spacing.

More generally, these results demonstrate a behavioral constraint (in this case likely due to predation risk from avian predators) on the use of water sources. Water source visitation represents a spatially and often temporally patterned activity that creates vulnerability. We should expect other species to demonstrate behavioral constraints. Mountain Quail (Oreortyz pictus), for example, were observed to prefer guzzlers within and near pinyon woodlands (Delehanty et al. 2004). Constraints must be considered by both managers and researchers interested in the effects of water developments.

\section{ACKNOWLEDGMENTS}

We thank members of the Utah Upland Game Advisory Committee for their support and volunteer time along with Travis Proctor and other members of the Utah Chukar and Wildlife Foundation. In addition, Susan Durham is thanked for her comments and review of the statistical approach.

\section{LITERATURE CITED}

Benolkin, P. J. 1988. Strategic placement of artificial watering devices for use by chukar partridge. In: G. K. Tsukamoto and S. J. Stiver [EDS.]. Las Vegas, NV: Wildlife Water Development Symposium. p. 59-62.

Benolkin, P. J., and A. C. Benolkin. 1994. Determination of a cost-benefit relationship between chukar populations, hunter utilization and the cost of artificial watering devices. Reno, NV: Nevada Department of Wildlife. $10 \mathrm{p}$.

BLoom, P. H., AND S. J. Hawks. 1982. Food habits of nesting golden eagles in northeast California and northwest Nevada. Journal of Raptor Research 16:110-115.

BoнL, W. H. 1957. Chukars in New Mexico. Santa Fe, NM: New Mexico Department of Game and Fish. 68 p.

BoycE, D. A. 1985. Prairie falcon prey in the Mojave Desert, California. Raptor Research 19:128-134.

Bunnell, K. D., J. T. Flinders, D. L. Mitchell, and J. H. Warder. 2004. Occupied and unoccupied sage grouse habitat in Strawberry Valley, Utah. Journal of Range Management 57:524-531. 
Christensen, G. C. 1970. The chukar partridge: Its introduction, life history, and management. Biological Bulletin No. 4. Reno, NV: Nevada Department of Fish and Game. 82 p.

Christensen, G. C. 1996. Chukar (Alectoris chukar). In: A. Poole and F. Gill [eds.]. The birds of North America. No. 258. Philadelphia, PA: The Academy of Natural Sciences, and Washington, DC: The American Ornithologists' Union, p. 1-20.

CUtLeR, T. L., AND D. E. Swann. 1999. Using remote photography in wildlife ecology: a review. Wildlife Society Bulletin 27:571-581.

DE'ATH, G., AND K. E. FABRICIUS. 2000. Classification and regression trees: a powerful yet simple technique for ecological data analysis. Ecology 81:3178-3192.

Degen, A. A., B. Pinshow, and P. U. Alkon. 1982. Water flux in chukar partridges (Alectoris chukar) and a comparison with other birds. Physiological Zoology 55:64-71.

Degen, A. A., B. Pinshow, and P. J. Shaw. 1984. Must desert chukars (Alectoris chukar sinaica) drink water? Water influx and body mass changes in response to dietary water content. Auk 101:47-52.

Delehanty, D. J., S. S. Eaton, and T. G. Campbell. 2004. From the field: mountain quail fidelity to guzzlers in the Mojave Desert. Wildlife Society Bulletin 32:588-593.

DICE, L. R. 1943. The biotic provinces of North America. Ann Arbor, MI: University of Michigan Press. 78 p.

Fenneman, N. M. 1931. Physiography of the western United States. New York, NY: McGraw-Hill Co. 534 p.

Galbreath, D. S., and R. Moreland. 1953. The chukar partridge in Washington. Biological Bulletin No. 11. Olympia, WA: Washington State Game Department. $55 \mathrm{p}$.

Guthery, F. S., L. A. Brennan, M. J. Peterson, and J. J. Lusk. 2005. Information theory in wildlife science: critique and viewpoint. Journal of Wildlife Management 69:457-465.

Hosmer, D. W., AND S. Lemeshow. 2000. Applied logistic regression. New York, NY: Wiley and Sons NY. $373 p$.

JonkeL, G. M. 1954. A comparative study of survival of fall and spring released chukar partridges (Alectoris graeca chukar) [thesis]. Missoula, MT: University of Montana. $70 \mathrm{p}$.

Laudenslager, M. L., and H. T. Hammel. 1977. Environmental temperature selection by the chukar partridge, Alectoris chukar. Physiology and Behavior 19:543-548.

Levene, H. 1960. Robust tests for equality of variances. In: I. Olkin [ed.]. Contributions to probability and statistics. Palo Alto, CA: Stanford University Press. p. 278-292.

LindBLoom, A. J. 1998. Habitat use, reproduction, movements, and survival of chukar partridge in west-central Idaho [thesis]. Moscow, ID: University of Idaho. $131 \mathrm{p}$.
Lindbloom, A. J., K. P. Reese, and P. Zager. 2003. Nesting and brood-rearing characteristics of chukars in west central Idaho. Western North American Naturalist 63:429-439.

LoNG, J. L. 1981. Introduced birds of the world: The worldwide history, distribution, and influence of birds introduced to new environments. New York, NY: Universe Books, New York. 528 p.

Main, M. B. 1996. Sexual segregation in Rocky Mountain mule deer. Journal of Wildlife Management 60:497-507.

MesserLI, J. R. 1970. Water in relation to the establishment of chukar partridge in Utah deserts [thesis]. Logan, UT: Utah State University. $39 \mathrm{p}$.

Müeller-Dombois, D., and H. Ellenberg. 1974. Aims and methods of vegetation ecology. New York, NY: John Wiley and Sons. 547 p.

Nevada Division of Wildulfe. 1999. Wildlife water development atlas. Reno, NV: Nevada Division of Wildlife. $77 \mathrm{p}$.

Nicolıs, K. E. 1961. Influences of "gallinaceous guzzlers" on selected chukar partridge population characteristics in western Colorado [thesis]. Fort Collins, CO: Colorado State University. $179 \mathrm{p}$.

OelkLaus III, W. F. 1976. Chukar partridge dispersion along the middle and lower Snake and Columbia rivers [thesis]. Moscow, ID: University of Idaho. $56 \mathrm{p}$.

Ramsey, F. L., And D. W. Schaffer. 2002. The statistical sleuth: A course in methods of data analysis. Pacific Grove, CA: Duxbury Press. 742 p.

Rosenstock, S. S., W. B. Ballard, and J. C. Devos, JR. 1999. Viewpoint: Benefits and impacts of wildlife water developments. Journal of Range Management 52:302-311.

Shaw, W. W. 1971. The effects of available water upon populations of chukar partridge on desert mountains of Utah [thesis]. Logan, UT: Utah State University. $61 \mathrm{p}$.

Shtatland, E. S., E. Cain, and M. B. Barton. 2001. The perils of stepwise logistic regression and how to escape them using information criteria and the output delivery system. Paper 222-226. 26th Annual SAS User's Group. Cary, NC: SAS Institute, Inc. 6 p.

Thornthwalte, C. W. 1931. The climates of North America according to a new classification. Geographical Review 21:633-655.

Turchi, G. M., P. L. Kennedy, D. Urban, and D. Hein. 1995. Bird species richness in relation to isolation of aspen habitats. Wilson Bulletin 107:463-474.

Vittinghoff, E., D. V. Glidden, S. C. Shiboski, and C. E. McCulloch. 2005. Regression methods in biostatistics: Linear, logistic, survival, and repeated measures models. New York, NY: Springer. $340 \mathrm{p}$.

WaLter, H. 2000. Ecology of the chukar in eastern Oregon [thesis]. Moscow, ID: University of Idaho. $123 \mathrm{p}$.

Walter, H. 2002. Natural history and ecology of the chukar (Alectoris chukar) in the northern Great Basin. Great Basin Birds 5:28-37. 